\title{
Disfungsi Organisasi Dagang di Luar Negeri Sebagai Aktor Diplomasi Indonesia
}

\author{
Rino F. Boer, Jessica Wongsodiharjo \\ London School of Public Relations Jakarta \\ Email : jewong13@gmail.com \\ Jl. K.H Mas Mansyur, Kav. 35, Jakarta Pusat 10220 \\ Phone: 021-5708123, Fax: 021-57904380
}

Submitted: 31 July 2019 Revised: 18 Agustus 2019 Accepted: 11 October 2019

\begin{abstract}
ABSTRAK
Keberadaan organisasi yang memperjuangkan kepentingan Indonesia di luar negeri seringkali hanya diasosiasikan dengan Kedutaan Besar Republik Indonesia (KBRI). Sesungguhnya ada organisasi dagang internasional yang ikut berperan penting dalam diplomasi misalnya INTCC di Bangkok. INTCC mengadakan berbagai kegiatan yang bertujuan untuk membantu kegiatan promosi iklim investasi di Indonesia kepada pengusaha-pengusaha lokal melalui berbagai pertemuan diplomasi dagang, seminar, Workshop, Business Forum, pameran investasi, hingga ke pertandingan olahraga. Namun, kenyataannya INTCC tidak berhasil mendapatkan dukungan penuh dari stakeholder-nya di Bangkok. Tujuan penelitian untuk mengindentifikasi faktor penyebab terjadinya disfungsi organisasi dagang ini sebagai aktor diplomasi Indonesia dengan menggunakan fully functioning society theory. Penelitian ini menggunakan pendekatan kualitatif dengan metode studi kasus yang menggunakan wawancara mendalam terhadap para informan. Kegagalan menjaga keseimbangan dalam mengakomodasi semua kepentingan stakeholders, social capital yang gagal terbentuk, serta kelemahan dalam penggunaan bahasa menjadi faktor utama penyebab kegagalan ini. Terbentuknya dukungan penuh dari masyarakat lokal, menjadi faktor kunci keberhasilan berperannya aktor-aktor diplomasi khususnya yang berasal dari non government official actor. Manfaat penelitian diharapkan dapat mengembangkan kajian atas proses engagement secara cepat, akurat dan efisien agar dapat mendorong peran organisasi di luar negeri supaya dapat berjalan lebih optimal sehingga menghasilkan ouput yang diharapkan.
\end{abstract}

Kata Kunci: disfungsi, diplomasi, masyarakat lokal, keterlibatan.

\section{ABSTRACT}

The existence of organizations that fight for the interests of Indonesia abroad is often only associated with the Indonesian Embassy (Indonesian Embassy). There are international trade organizations that play an important role in diplomacy such as the INTCC in Bangkok. INTCC held various activities aimed at assisting the promotion of the investment climate in Indonesia to local entrepreneurs through various trade diplomacy meetings, seminars, workshops, business forums, investment exhibitions, to sports competitions. However, in reality, INTCC did not succeed in getting full support from its stakeholders in Bangkok. The research objective is to identify the factors that cause the disfunction of this trade organization as an Indonesian diplomacy actor by using fully functioning society theory. This study uses a qualitative approach with a case study method that uses in-depth interviews with informants. Failure to maintain balance in accommodating all the interests of stakeholders, social capital that fails to form, and weaknesses in the use of language are the main factors causing this failure. The formation of full support from the local community is a key factor in the success of diplomatic actors, especially those from non-government official actors. The benefits of the research are expected to be able to develop studies on the engagement process quickly, accurately and efficiently to encourage the role of organizations abroad so that they can run more optimally to produce the expected output.

Keywords: engagement, diplomacy, dysfunction, local people 
PENDAHULUAN

Kerjasama antar negara utamanya dilakukan oleh Kedutaan Besar Republik Indonesia (KBRI) yang berjuang untuk kepentingan Indonesia di negara lain. Menurut data dari Kementerian Luar Negeri Indonesia per tahun 2019, Indonesia menjalin hubungan kerjasama bilateral dengan 162 negara dan di masing-masing negara memiliki Kedutaan Besar Republik Indonesia. KBRI sebagai perwakilan pemerintah kerap diandalkan oleh masyarakat Indonesia sebagai institusi yang membantu semua permasalahan yang berkaitan dengan Indonesia melalui diplomasi. Seiring berjalannya waktu, permasalahan lintas negara dalam bidang ekonomi, industri ekspor, impor dan investasi semakin beragam dan kompleks.

Pada Era Globalisasi ini, menurut (Strange, 2015) telah lahir 'diplomat' baru dalam sistem ekonomi global yakni perusahaan/organisasi. Perusahaan memunculkan Triagular Diplomacy yaitu diplomasi antara negara dan negara, perusahaan dan perusahaan, serta negara dengan perusahaan. Dalam perkembangannya muncul beragam bentuk dan jenis diplomasi salah satunya adalah diplomasi ekonomi yang bentuknya semakin kompleks seiring dengan kemunculan non-governmental organizations dan international organizations. Ketidakpuasan atas kinerja aktor diplomasi tradisional dalam menghadapi perubahan eksternal dan internal yang begitu cepat menimbulkan harapan besar atas meningkatnya peran dari non state actors. Penelitian Breslin dan Nesadural (2017) mencatat bahwa non-state actors yang diharapkan ini berasal dari multinational
corporations/MNC, non governmental organization/NGO, asosiasi industry, yayasan philantropi, perusahaan, serta para ahli di bidang masing-masing.

Perluasan aktor dalam hubungan internasional serta aktivitas ekonomi juga mengalami perluasan pelaku dengan semakin dominannya pelaku swasta. Terkadang swasta disebut sebagai aktor utama dibalik aktifitas ekonomi negara. Individu, kelompok dan perusahaan swasta dapat turut berkontribusi terhadap perekonomian negara. Kompeksitas hubungan internasional membuat banyaknya ragam non governmental organization yang mengambil peran dalam diplomasi antar negara.

$$
\text { Badan Pusat Statistik (BPS) }
$$
mencatat secara kumulatif nilai ekspor Indonesia periode Januari hingga Desember 2016 turun sebanyak 3,95\% dibanding tahun 2015 pada periode yang sama (Yovanda, 2017). Dibutuhkan kemitraan antar instansi agar dapat menembus pasar di luar negeri dengan lebih efektif. Ketidakjelasan strategi pemerintah dalam perdagangan luar negeri dan sulitnya mencari Indonesia Trade Centre di luar negeri menjadi masalah prioritas bagi pemerintah Indonesia.

Perkembangan masalah ekonomi dan perdagangan yang semakin kompleks, membuat negara membutuhkan peran aktor non governmental dan tidak lagi cukup pada hanya mengandalkan peran pemerintah secara langsung. Ketua Umum Kadin Indonesia, Suryo Sulisto menyatakan bahwa diplomasi perdagangan internasional oleh pemerintah Indonesia tergolong lemah terlihat dari beban yang ditanggung pengusaha nasional. Contoh: 1) Kerjasama ACFTA (Asean-China Free Trade Area) yang dinilai menghancurkan 
usaha kecil dan menengah serta membuat industri nasional mati suri dengan gejala massal terjadinya deindustrialisasi. 2) Setiap ada usaha negosiasi baru dengan asing, maka dunia usaha dan publik merespon dengan tegas menolak keras tanpa mengetahui isi negosiasi dagang tersebut. 3) Secara historis kinerja pemerintah Indonesia dalam diplomasi ekonomi masih lemah sehingga publik dan dunia usaha kurang percaya (Skalanews, 2015).

Hal ini dibuktikan data dari Kementerian Perdagangan dalam (LokaData, 2018) bahwa nilai ekspor Indonesia ke Thailand pada tahun 2018 sebesar US\$6,8 juta atau meningkat 5,33 persen dibandingkan tahun sebelumnya. Peningkatan ekspor ini diikuti juga dengan meningkatnya impor Indonesia dari Thailand sebesar US\$11 juta atau meningkat 18,01 persen dibandingkan tahun sebelumnya. Peningkatan impor yang jauh lebih besar dibandingkan ekspor, menyebabkan neraca perdagangan Indonesia dan Thailand defisit sejak tahun 2013 hingga 2018. Diketahui besarnya defisit neraca perdagangan tahun 2018 yakni US\$-4,1 juta. Defisit ini kedua tertinggi selama enam tahun terakhir (LokaData, 2018), dalam kasus CAFTA, Indonesia berada di pihak yang dirugikan dengan korban pengusaha sektor industri dan agrobisnis.

Dibutuhkan peran lebih besar dari organisasi kamar dagang dan industri sebagai organisasi non-government dalam membentuk kelompok organisasi bisnis di luar negeri. Peran organisasi kamar dagang di LN ini menjadi penting sebagai mitra pemerintah yang menjembatani wadah komunikasi dan konsultasi mengenai hal yang berkaitan dengan masalah perdagangan. Organisasi ini turut menopang sebagai promotor, fasilitator dan juga terlibat dalam proses pengambilan kebijakan terkait bisnis. Keterlibatan Indonesia melalui organisasi Kamar Dagang dan Industri dalam ekonomi internasional dituntut semakin aktif untuk menjawab tantangan yang semakin bertambah dan melibatkan banyak pihak sebagai stakeholders atau pihak-pihak yang berkepentingan dalam arus perdagangan internasional dimanapun pengusaha ini berada (Saputra, 2017). Stakeholders yang dimaksud adalah pihak atau setiap kelompok yang berada di dalam maupun di luar organiasi yang mempunyai peranan penting dalam menentukan keberhasilan organiasi. Menurut Kasali dalam (Putri, 2014), stakeholders dibagi menjadi dua kelompok besar adalah stakeholders internal dan stakeholders eksternal. Namun demikian, dalam kerangka hubungan internasional terdapat istilah multi-stakeholders partnership atau transnational publicprivate partnership yang mengacu kepada peningkatan peran private sectors sebagai pemegang otoritas yang makin signifikan dalam era globalisasi (Menashy, 2016). Bahkan menurut Babic, Fichtner, \& Heemskerk (2017) kiprah perusahaan sebagai aktor diplomasi telah menjadi fokus utama penelitian-penelitian tentang international relations/IR dan internasional political economy/ IPE pada saat ini.

Hubungan diplomatik antara Indonesia dan Thailand telah bertahan 67 tahun sejak 7 Maret 1950. Selama 67 tahun ini, berbagai kerjasama telah dibentuk dan dilakukan hampir di semua sektor antara lain bisnis, perdagangan, ekonomi, pendidikan, politik dan 
keamanan. Pertukaran kunjungan antara negara dan pemimpin organisasi fungsional Indonesia dan Thailand telah saling mengembangkan pemahaman yang bermanfaat antar pemerintah (Kemlu, 2017)

Thailand menjadi salah satu destinasi ekspansi bisnis dan menjadi peringkat kedua sebagai negara penerima arus masuk FDI terbesar di ASEAN. Menurut (Worldometers, 2019; Worldometers, 2019), Thailand juga mempunyai penduduk sebesar 69.306 .847 pada Juli 2019 dengan menempati posisi penduduk ke-4 terbanyak di ASEAN setelah Indonesia, Filipina dan Vietnam. Perdagangan adalah sektor penting bagi perekonomian Thailand. Pertumbuhan ekonomi rata-rata $17,4 \%$ per tahun sedangkan per tahunnya diperkirakan meningkat sebesar $12,5 \%$ lebih. Pasar utama negara ekspor adalah Amerika Serikat, Jepang, Uni Eropa dan Perhimpunan Bangsa-bangsa Asia Tenggara (ASEAN) sementara pasar baru yang menjadi negara tujuan ekspor adalah China, Asia Selatan, Afrika dan IndoTiongkok. Menurut data dari Heritage.com, tahun 2017 nilai ekspor dan impor Thailand sebesar $132 \%$ dari Produk Domestik Bruto (PDB).

Organisasi non-state actor yang ikut berperan dalam diplomasi perdagangan Indonesia dan Thailand selama ini adalah INTCC (Indonesia Thai Chamber of Commerce). Kehadiran INTCC yang sudah berdiri selama kurang lebih enam tahun sejak tahun 2013 di Thailand dan telah bekerja sama dengan Kedutaan Republik Indonesia di Bangkok sejak kehadirannya. Organisasi pengusaha ini mengadakan berbagai acara yakni agenda pertemuan, seminar, Workshop,
Business Forum, pertandingan olahraga, pameran investasi Indonesia dan kegiatan lainnya bekerjasama dengan KBRI. Kegiatan INTCC ini telah memberikan dampak positif kepada peningkatan investasi Thailand ke berbagai sektor di Indonesia. Wakil Menteri Luar negeri A.M.Fachir menyampaikan bahwa pemerintah akan terus mendorong peningkatan investasi Thailand ke berbagai sektor di Indonesia. Investasi Thailand ke Indonesia dalam dua tahun terakhir telah meningkat sebesar 300 persen yaitu sekitar 106 juta dollar AS pada 2013 menjadi lebih dari 318 juta dollar AS pada 2014. Dalam perekonomian, memang diperlukan kerja sama pada level pengusaha secara individu dengan partner dagang dari negara lain. Hal Ini dilakukan sebagai upaya mengatasi hambatan dalam perdagangan untuk mendorong transaksi ekonomi di negara asal investor yang secara tidak langsung berdampak pada peningkatan pendapatan negara secara nasional (Skalanews, 2015).

Dalam rangka mendukung penelitian, peneliti menganalisis dua penelitian yang memiliki keterkaitan dengan penelitian ini. Artikel pertama diambil dari Heath (2011) yang berjudul Onward Into More Fog: Thoughts on Public Relations' Research Directions yang membahas mengenai pentingnya masyarakat bagi organisasi. Keberadaan sebuah organisasi terkait dengan kapasitasnya memenuhi atau melampaui harapan normatif para Stakeholders di sekeliling organisasi terutama masyarakat. Ketika organisasi melanggar harapan masyarakat, maka organisasi tersebut kehilangan legitimasinya. Fully Functioning Society Theory adalah pendekatan yang menggambarkan 
legitimasi sebuah organisasi dengan melihat hubungan organisasi dengan masyarakat sekitar.

Selanjutnya dikutip dari artikel yang ditulis oleh Setyowati (2016) yang menjelaskan diplomasi dalam ekonomi bilateral merupakan media yang paling dominan dan menjadi salah satu kunci utama keberhasilan negara-negara berkembang dalam memanfaatkan peluang dari globalisasi ekonomi. Organisasi Internasional Kamar Dagang dan Industri (Kadin) memberi perhatian besar bagi kegiatan yang mendorong perekonomian dalam negeri. Kadin Provinsi Jawa Tengah turut berbenah menopang dalam kapasitas perannya sebagai mitra pemerintah, fasilitator, promotor dan juga terlibat dalam proses pengambilan kebijakan terkait bisnis di Indonesia. Perluasan aktor dalam hubungan international, aktivitas ekonomi juga mengalami perluasan pelaku dengan semakin dominannya pelaku swasta. Pelaku swasta saat ini yang sering disebut sebagai aktor utama dibalik aktifias ekonomi negara. Tumbuhnya kesadaran yang semakin luas untuk menerapkan diplomasi multi jalur melalui stakeholders untuk bekerjasama dan mencapai kepentingan negara.

Peran INTCC di Thailand sebagai aktor ekonomi bertujuan untuk menciptakan kemajuan dalam perdagangan dan industri Indonesia. Walau faktanya, keberhasilan merealisasikan belumlah begitu besar karena memang menemui beberapa hambatan. Ditemukan hambatan internal dan eksternal pada organisasi INTCC sehingga memberikan dampak yang kurang signifikan kepada bisnis pengusaha Indonesia di Thailand. Salah satunya karena masih minimnya dukungan stakeholders organisasi termasuk pengusaha yang tergabung di dalam organisasi, masyarakat Thailand, serta masyarakat Indonesia di Thailand. Menurut Dewi Widowati (2013), komunikasi sebagai jalan memahami pentingnya budaya organisasi dalam perusahaan. Para pemimpin tertinggi organisasi (chief executive officials) harus memahami budaya organisasi yang ada dan yang sedang beroperasi dalam organisasinya. Banyak cara yang dapat dijadikan sebagai upaya untuk mempertahankan budaya organisasi. Misalnya dengan memberikan imbalan atau promosi bagi karyawan yang perilakunya konsisten dengan budaya organisasi. Sebaliknya juga mempertahankan budaya organisasi, terkadang dengan memberikan sanksi bagi mereka yang melanggar norma, nilai-nilai, atau kode etik organisasi (Widowati, 2013).

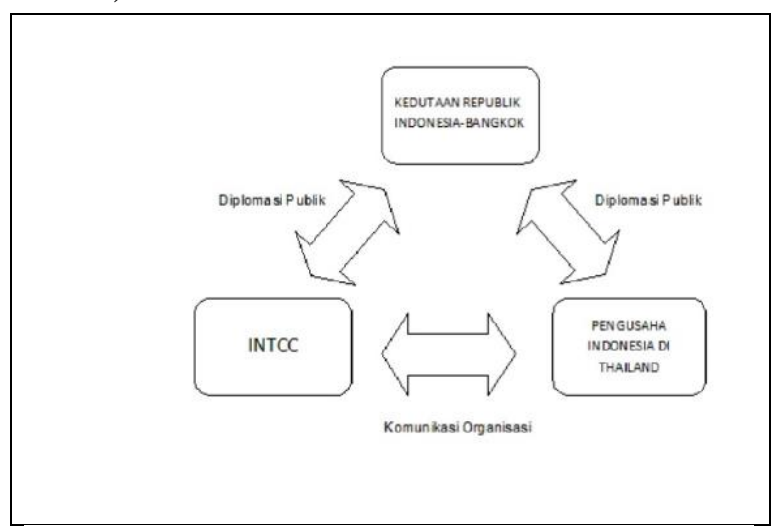

Sumber: Data Olahan Peneliti, 2017

Gambar 1. Hubungan INTCC, Pengusaha Indonesia di Thailand dan Kedutaan Republik Indonesia-Bangkok

Organisasi merupakan suatu kesatuan atau perkumpulan yang terdiri atas orang-orang/bagian-bagian yang di dalamnya terdapat aktivitas kerja sama berdasarkan pola dan aturan-aturan untuk mencapai tujuan bersama. Keterlibatan aktif dalam berpartisipasi, bukan hanya 
berarti keterlibatan fisik semata. Partisipasi dapat diartikan sebagai keterlibatan mental, pikiran, dan emosi atau perasaan seseorang dalam keadaan yang mendorongnya untuk memberikan sumbangan kepada kelompok dalam usaha mencapai tujuan serta turut bertanggung jawab terhadap usaha yang bersangkutan (Hasan, 2010). Anggota organisasi harus memiliki kemampuan untuk berpartisipasi, dalam arti yang bersangkutan memiliki luas lingkup pemikiran dan pengalaman yang sama dengan komunikator, dan kalaupun belum ada, maka unsur-unsur itu mampu ditumbuhkan oleh komunikator. Partisipasi dalam organisasi menekankan pada pembagian wewenang atau tugas dalam melaksanakan kegiatannya dengan maksud meningkatkan efektifitas kewajiban yang diberikan secara terstruktur dan lebih jelas (Hasan, 2010). Konsep engagement atau keterlibatan stakeholders dengan perusahaan, di dalam studi public relations telah berjalan sejak 20 tahun yang lalu dimulai dari studi terhadap cognitive involvement di dalam kampanye (Johnston, 2014). Namun demikian, menurut Heath (2011) seperti yang dikutip dari Johnston (2014), topik pembahasannya kini telah berubah ke isu seperti pengembangan komunitas, membangun hubungan yang sifatnya mutual inklusif, serta yang terkini adalah peningkatan partisipasi stakeholders di dalam aktivitas organisasi. Hal ini dipertegas oleh Ferguson (2018) yang menyatakan pengembangan teori dan penelitian di dalam public relations seharusnya tidak lagi bicara tentang organisasi, publik, atau proses komunikasi di dalamnya, tetapi hubungan antara organisasi dengan publik. Oleh karena itu, penelitian ini menggunakan teori dan konsep sebagai berikut:

1. Untuk melihat bagaimana relasi organisasi dengan stakeholders utamanya, maka penelitian ini menggunakan Fully Functioning Society Theory. Organisasi tidak lagi bersifat otonom, kepentingan publik dan pemangku kepentingan (Stakeholders) memiliki kemampuan untuk memberikan pengaruh yang signifikan terhadap organisasi. Menurut Robert Heath dalam Taylor (2011), Fully Functioning Society Theory (FFST) membahas pentingnya masyarakat bagi organisasi. Hal ini tergantung pada berbagai proses budaya, sosial, ekonomi, dan politik yang dibutuhkan untuk menciptakan modal sosial. Kepentingan individu dan organisasi bertemu saat keduanya berusaha mengkomunikasikan agenda masingmasing. Hubungan organisasi dengan masyarakat berperan penting dalam publikasi agenda organisasi melalui kegiatan organisasi dalam diskusi masyarakat publik. Hubungan masyarakat dengan organisasi merupakan modal sosial yang dibutuhkan masyarakat.

Hubungan organisasi dengan pemangku kepentingan sekitar organisasi dapat memberi nilai tambah bagi masyarakat jika dapat berfungsi penuh. Ada delapan premis yang mengartikulasikan peran pemangku kepentingan (stakeholders) termasuk kegiatan organisasi dalam membuat masyarakat menjadi tempat tinggal yang lebih baik menurut Heath dalam 
(Taylor, 2011) yaitu: Heath's premises can be summarized as follows: 1) Management works to bring order to uncertainty, 2) Corporate responsibility, 3) Power resource management, 4) Community as conflicting and conjoined interests and expectations, 5) Relationship as symmetry: communities versus corporates, 6) Organizational communication, 7) Responsible advocacy, 8) Narrative and other forms of rhetoric leading to enlightened choice Fully Functional Society Theory menjelaskan di dalam premisnya bagaimana hubungan komunikasi yang baik antara organisasi dan masyarakat dapat membuat masyarakat menjadi tempat tinggal yang nyaman bagi organisasi. Visi Heath dalam menciptakan FFST memberikan pesan tersirat bahwa hubungan antara organisasi dan kelompok menciptakan modal sosial yang membuat masyarakat lebih kuat dan lebih mampu memenuhi kebutuhan anggotanya. Dimana modal sosial adalah hasil dari orientasi organisasi, kapasitas organisasi untuk menanggapi posisi yang dianjurkan oleh publik, dan advokasi kolektif (melalui retorika dan hubungan masyarakat) dari berbagai aktor untuk memajukan pilihan untuk keuntungan masyarakat. Hubungan masyarakat adalah pemberlakuan publikasi organisasi, dan bersama-sama membantu menciptakan modal organisasi dan sosial (Heath, 2011).

2. Untuk melihat hubungan INTCC dengan Pemerintah Indonesia, Pemerintah Thailand, komunitas dan penggunaan media sosial, maka penelitian ini menggunakan konsep diplomasi publik sebagai instrumen soft power. Diplomasi Publik dimaknai sebagai proses komunikasi pemerintah terhadap publik mancanegara yang bertujuan untuk memberikan pemahaman atas negara, sikap, institusi, budaya, kepentingan nasional, dan kebijakan-kebijakan yang diambil oleh negaranya. Dampak yang ditimbulkan meliputi bidang politik, ekonomi, sosial, dan dalam pelaksanaannya tidak lagi dimonopoli oleh pemerintah, tetapi ada peranan organisasi. Oleh karena itu, INTCC sebagai organisasi kamar dagang antara Indonesia dan Thailand mempunyai peran diplomasi bilateral dalam bidang perdagangan, bisnis dan investasi. Dalam perkembangannya soft power seringkali dikaitkan dengan keberhasilan praktek diplomasi yang dilakukan oleh aktor internasional, salah satunya adalah berperan penting pada masa Perang Dingin. Hal ini karena diplomasi publik adalah bagaimana aktor internasional menggunakan berbagai macam sumber daya yang dimiliki untuk berkomunikasi dan menarik perhatian publik internasional demi tercapainya kepentingan nasional yang terencana dimana budaya menjadi salah satu aspek penting di dalamnya (Nye, 2008) 


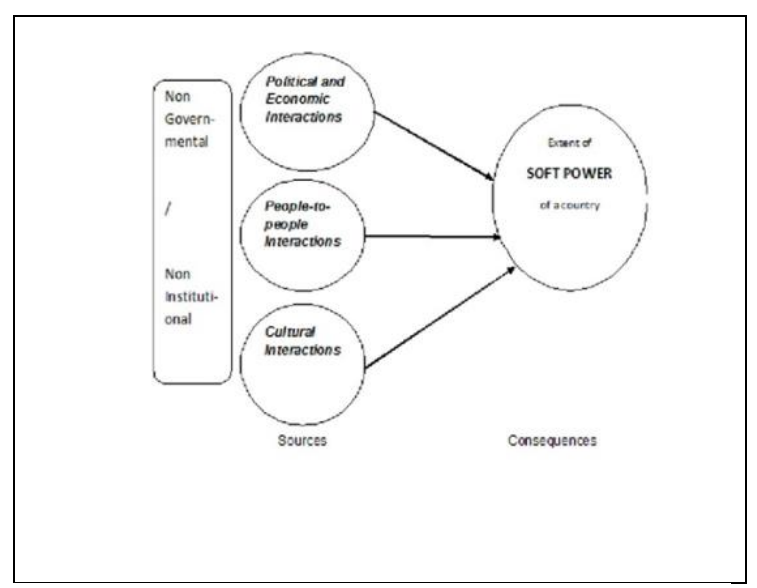

Sumber: Kim \& Ni, 2011

\section{Gambar 2. Koseptualisasi dimensi Soft} Power

Karakteristik soft power yang mempengaruhi hubungan, perilaku dan reputasi sebuah negara terhadap publik internasional, menurut (Kim \& Ni, 2011), yakni Political and Economic Interactions, People-to-people Interactions dan Cultural Interaction. Ketiga dimensi tersebut memegang peranan penting bagi aktoraktor internasional untuk menyebarkan pengaruh dan ide-ide yang dimilikinya kepada publik internasional sehingga hal tersebut dapat membentuk sebuah citra positif yang atraktif (soft power) bagi aktor internasional yang bersangkutan. Hal tersebut menjadi bukti nyata bahwa secara langsung dan tidak langsung diperlukan soft power bagi para aktor internasional dalam rangka memperjuangkan kepentingan aktor di level regional dan global.

Tugas sebuah organisasi tidak hanya melakukan aktivitas yang hanya menjadi rutinitas dari organisasi tersebut, tetapi juga adanya penetrasi pasar bersama dengan semua stakeholders INTCC. Aktivitas organisasi INTCC yang diselenggarakan dalam pertemuan diplomasi dagang, seminar, Workshop, Business Forum, pameran investasi, hingga ke pertandingan olahraga bertujuan untuk membantu pengusaha Indonesia melakukan ekspor ke Thailand. INTCC bekerja sama dengan Kedutaan Besar Republik Indonesia di Bangkok membantu perluasan bisnis yang terintegrasi di Thailand dengan menjalin hubungan baik dengan pemerintah Thailand, masyarakat Indonesia dan masyarakat Thailand di Thailand. Namun sejauh ini, respons masyarakat di kedua negera ini masih sangat minim padahal INTCC adalah institusi swasta yang juga mendapat izin dari Kerajaan Thailand yang seharusnya memiliki akses luas baik di Thailand terlebih lagi di Indonesia. Penelitian ini mengindentifikasi apa yang menjadi penyebab kegagalan berfungsinya INTCC di Bangkok, Thailand dan menganalisa menggunakan Fully Functioning Society theory dari Robert Heath untuk menjelaskan fenomena.

\section{METODE PENELITIAN}

Penelitian ini menggunakan pendekatan kualitatif dalam mengindentifikasi penyebab kegagalan organisasi INTCC sebagai aktor diplomasi yang non-tradisional. Metode kualitatif yang digunakan adalah studi kasus dengan sifat penelitian deskriptif. Menurut Robert K. Yin (2003), metode studi kasus paling tepat digunakan untuk menjelaskan pertanyaan tentang 'mengapa' dimana peneliti mempunyai keleluasaan dalam memilih kasus yang kontemporer daripada menggunakan pendekatan historis. Melalui studi kasus akan diperoleh gambaran hubungan INTCC dengan stakeholders dan juga antar member anggota INTCC. Sifat Penelitian yang diambil yaitu deskriptif, menggambarkan sifat suatu keadaan yang sementara berjalan pada saat penelitian dilakukan, 
dan memeriksa sebab-sebab dari suatu gejala tertentu. Metode penelitian kualitatif deskriptif ini tidak terbatas pada pengumpulan dan penyusunan data, tetapi meliputi analisis dan interpretasi tentang arti data itu, menjadi suatu wacana dan konklusi dalam berpikir logis, praktis, dan teoritis. Penelitian ini menggunakan metode wawancara mendalam (in-depth interview) dengan tiga informan: dua informan dari organisasi INTCC dan satu dari perwakilan KBRI Bangkok.

Adapun teknik wawancara yang dilakukan menggunakan wawancara semi terstruktur sehingga pertanyaan terbuka kepada informan, informan dapat menjawab pertanyaan yang diajukan dengan lebih leluasa dan memungkinkan bagi penulis untuk mendapatkan jawaban yang berkembang di luar pertanyaan terstruktur tetapi tidak terlepas dari permasalahan yang ingin dibahas. Indikator pemilihan informan yaitu informan yang terlibat dengan organisasi INTCC dan mempunyai peranan dalam membuat atau menjalankan organisasi INTCC sesuai dengan topik penelitian. Sumber pendukung untuk melengkapi penelitian dengan literatur tambahan pendukung yang digunakan adalah studi kepustakaan seperti buku, jurnal, artikel, karya ilmiah lainnya dan situs resmi mengenai organisasi INTCC.

Teknik analisis data yang digunakan dalam penelitian kualitatif ini menggunakan yaitu melakukan reduksi data dengan merangkum, memilih hal-hal pokok, memfokuskan pada hal - hal yang penting dan mencari tema dan polanya sehingga dapat memberikan gambaran jelas pada paparan data. Pemaparan data sebagai sekumpulan informasi tersusun, data penelitian disajikan dalam bentuk uraian yang didukung dengan tabel dan grafik. Pemaparan data yang tersusun memberi kemudahan pada penarikan kesimpulan dan verifikasi. Penarikan kesimpulan merupakan hasil penelitian yang menjawab fokus penelitian berdasarkan hasil penelitian data dalam bentuk deskriptif objek penelitian dengan berpedoman pada kajian penelitian.

\section{HASIL DAN PEMBAHASAN}

Organisasi INTCC awalnya didirikan atas inisiatif pengusaha Indonesia untuk membuat komunitas dagang di Thailand. Inisiatif pengusaha Indonesia disambut baik oleh KBRI Bangkok yang ikut mendukung INTCC sebagai salah satu organisasi yang terdaftar di bawah Kementerian Perdagangan Thailand. Board of Directors (BOD) INTCC terdiri dari pengusaha Indonesia yang melakukan bisnis dan investasi di Thailand yang memegang jabatan penting dalam organisasi. Peran BOD inilah yang mendukung penuh berjalannya organisasi INTCC baik dalam pertemuan rutin maupun aktivitas organisasi INTCC.

Tujuan didirikannya INTCC adalah dalam rangka membantu pengusaha Indonesia melakukan ekspor ke Thailand sehingga dapat meningkatkan kemajuan ekonomi Indonesia menghadapi Masyarakat Ekonomi ASEAN tahun 2015. Ketika itu INTCC sebagai organisasi kamar dagang antara Indonesia dan Thailand (bilateral) juga turut membantu pengusaha Thailand dalam melakukan ekspor ke Indonesia. Stakeholders organisasi INTCC yaitu pengusaha Indonesia di Thailand, pengusaha Thailand di Thailand, pemerintah Indonesia, masyarakat Indonesia di Thailand, 
masyarakat Thailand di Thailand dan masyarakat Indonesia di Indonesia, pemerintah Thailand, Pemerintah Indonesia, komunitas Indonesia di Thailand dan komunitas Thailand di Thailand.

Aktivitas organisasi INTCC yang disusun oleh Board of Directors (BOD) INTCC tergolong masih kurang dengan hanya menyelenggarakan minimal empat sampai enam acara per tahunnya. Hal ini disebabkan Partisipasi anggota member BOD INTCC yang kurang aktif dalam organisasi dan kesibukan bisnis pribadi para pengusaha Indonesia di Thailand. Dimana aktivitas organisasi INTCC diselenggarakan untuk meningkatkan hubungan networking organisasi dan member anggota INTCC sehingga diharapkan dapat menjalin hubungan bisnis dan investasi. Hubungan antar member anggota INTCC terutama Board of Directors (BOD) mempunyai peranan besar terhadap terlaksananya aktivitas komunikasi organisasi INTCC. Hal ini menunjukan partisipasi member anggota member INTCC yang terdiri dari pengusaha Indonesia dan Thailand mendukung terbatas terhadap aktivitas organisasi INTCC seperti jadwal pertemuan rutin yang hanya dilakukan dua minggu sekali dan juga kehadiran para pengusaha.

Aktivitas organisasi INTCC yang diselenggarakan selama ini dalam bentuk business matching, pameran bisnis, seminar \& talkshow, Social Work, Networking night, dan turnamen olahraga. Aktivitas organisasi INTCC seperti pertemuan diplomasi dagang, Business Forum, Business Matching dan acara pertemuan bisnis lainnya, INTCC memberikan fasilitas secara khusus kepada member anggota termasuk pengusaha Indonesia untuk melakukan negosiasi dan ekspansi bisnis dengan memperkenalkan produk lokal dan jasa kepada pemerintah dan pengusaha Thailand. Dalam rangka mendukung pengusaha Indonesia, INTCC memberikan bantuan negosiasi, fasilitator dan solusi dalam bidang bisnis secara personal. Sayangnya organisasi INTCC ini lebih dimanfaatkan oleh pengusaha Thailand dalam melakukan ekspor dan investasi ke Indonesia daripada pengusaha Indonesia melakukan bisnis ke Thailand.

Organisasi INTCC juga melibatkan masyarakat Indonesia dan masyarakat Thailand di Thailand melalui aktivitas organisasi INTCC yaitu seminar, Workshop, pameran investasi dan pertandingan olahraga. Kegiatan ini tidak hanya melibatkan pengusaha, tetapi juga masyarakat Indonesia dan masyarakat Thailand di Thailand. Hal ini menunjukkan bahwa INTCC berusaha membangun reputasi dan dikenal luas sehingga masyarakat Thailand dapat memberikan dukungan kepada organisasi INTCC. Aktivitas organisasi INTCC juga berkontribusi pada masyarakat Thailand di Thailand melalui Social Event dan donasi yang disalurkan melalui lembaga Red Cross, yayasan amal di Wat Pho dan lembaga amal lainnya. Aktivitas organisasi INTCC pada masyarakat Indonesia di Thailand antara lain mengundang masyarakat Indonesia dalam Thai National Day, menggalang diaspora Indonesia di Thailand dan mensosialisasikan pajak Indonesia dan kebijakan hukum Thailand bagi pengusaha di kedua negara.

Hubungan INTCC dengan Perwakilan pemerintah Indonesia di Bangkok yaitu KBRI Bangkok, mendukung penuh organisasi INTCC 
sama halnya seperti ketika KBRI Beijing mendukung Indonesia Chamber of Commerce (INAHCAM) di China. INAHCAM sebagai organisasi kamar dagang yang berusia lebih muda dari INTCC sudah dilibatkan dalam penyelenggaraan acara kemerdekaan Indonesia di KBRI Beijing pada tahun 2015. INTCC dalam aktivitas organisasi INTCC melibatkan KBRI Bangkok juga sebagai pelindung dan patron yang membantu mempromosikan INTCC serta mendukung aktivitas organisasi INTCC yaitu mengundang kedutaan besar negara lainnya yang ada di Thailand, mengirim perwakilan KBRI Bangkok untuk hadir dalam acara INTCC dan membantu broadcast event INTCC kepada masyarakat Thailand dan Indonesia di Thailand.

Hubungan INTCC dengan masyarakat Indonesia di Thailand dan masyarakat Thailand di Thailand terjalin melalui berbagai kegiatan acara yang dilakukan. Dukungan INTCC terhadap masyarakat Indonesia di Thailand dengan mewakili masyarakat Indonesia di Thailand melalui event Thailand seperti Thai National Day, membantu masyarakat Indonesia bersama dengan KBRI, melakukan kerja sosial sumbangkan untuk Red Cross, membantu kerjasama Suphaburi FC dengan Bali FC dalam pertukaran pemain sepak bola dan menggalang diaspora Indonesia di Thailand. Demikian sebaliknya dukungan INTCC untuk masyarakat Thailand di Thailand yaitu dengan cara membantu masyarakat Thailand yang ingin melakukan investasi di Indonesia, membantu mencari distributor di Indonesia, memberikan info seminar dan trade Expo di Indonesia, mensosialisasikan pajak dari Indonesia dan kebijakan hukum Thailand. Masyarakat Thailand juga berpartispasi pada event yang dibuat oleh INTCC dan KBRI Bangkok. Sedangkan untuk aktivitas organisasi INTCC dalam mendukung masyarakat Thailand yaitu Social Event yang diselenggarakan oleh INTCC seperti acara olahraga dan pameran, social work membantu anak yatim di Thailand dan membantu Yayasan amal di Wat Pho.

Organisasi INTCC sebagai organisasi yang menjembatani kedua negara menjalin hubungan dengan pemerintah Thailand, pemerintah Indonesia di Indonesia, serta beberapa komunitas yang ada di Indonesia dan Thailand. Peranan pemerintah Thailand, pemerintah Indonesia di Indonesia, komunitas, organisasi dan sesama chamber mendukung terbatas pada aktivitas organisasi INTCC. Pemerintah Thailand berkontribusi dalam legalitas berdirinya organisasi INTCC melalui surat perijinan dari Kementrian Perdagangan dan mengundang perwakilan pemerintah Thailand dalam aktivitas organisasi INTCC. INTCC juga mendukung pemerintah Thailand dalam mempromosikan 4.0 digital economy dengan promosi menggunakan basis teknologi, Website INTCC yang dikembangkan di Indonesia dan Thailand. Dimana aktivitas organisasi INTCC yang selama ini diselenggarakan melibatkan Thai Chamber of commerce, Kementrian Perdagangan Thailand, KBRI Bangkok, Asosiasi Rice Export, Thai Otomotive, Kassat University dan lainnya. Demikian sebaliknya, Hubungan INTCC dengan pemerintah Indonesia mendukung secara terbatas melalui peranan KBRI Bangkok mengundang salah satu pejabat negara 
Indonesia untuk menjadi pembicara di acara INTCC. INTCC juga membantu memenuhi permintaan dari pemerintah Indonesia mengenai informasi salah satu sektor yang ada di Thailand, serta membuat meeting dengan pejabat pemerintah Indonesia di Thailand

Hubungan INTCC dengan komunitas Indonesia yang ada di Thailand mendukung dalam aktivitas organisasi INTCC dengan mengundang PERMITHA (Perhimpunan Mahasiswa IndonesiaThailand) hadir dalam acara INTCC dan membantu Dharma Wanita di Thailand menyelenggarakan acara coorporate Social Responsibility (CSR). Hubungan INTCC dengan komunitas Thailand di Thailand mendukung dalam penyelenggaraan aktivitas organisasi dengan Thai Chamber of commerce, Joint Foreign Chamber of Commerce (JFCCT), Asosiasi Rice Export, Thai Otomotive, dan Kassat University.

Organisasi INTCC memanfaatkan perkembangan teknologi dan internet untuk menjalin hubungan dengan masyarakat Indonesia di Indonesia melalui media sosial Facebook, Line dan website. Disayangkan INTCC masih kurang maksimal dalam mengelola dan melakukan update website INTCC. Padahal promosi aktivitas komunikasi organisasi INTCC melalui media sosial seperti Facebook INTCC dan email masih menjadi satu-satunya akses untuk directcontact kepada INTCC yang diberikan untuk masyarakat Indonesia dan calon pengusaha Indonesia yang ingin melakukan investasi ke Thailand melalui INTCC. Padahal menurut Zhang \& Abitbol (2014), penggunaan media sosial oleh perusahaan berpengaruh siginifikan terhadap engagement perusahaan dengan warga sipil melalui peningkatan persepsi terhadap orientasi sosial perusahaan.

Aktivitas organisasi INTCC lebih banyak dilakukan di Thailand daripada di Indonesia. Padahal salah satu tujuan utama organisasi INTCC ini adalah untuk membantu masyarakat Indonesia di Indonesia termasuk di dalamnya pengusaha Indonesia untuk melakukan bisnis di Thailand. Organisasi INTCC ini seharusnya lebih dikenal di kalangan masyarakat Indonesia di Indonesia dan pengusaha Indonesia di Indonesia melalui berbagai aktivitas organisasi yang dilakukan. Aktivitas organisasi INTCC yang diselenggarakan di Indonesia bertujuan untuk menunjukkan eksistensi dan reputasi INTCC sebagai organisasi kamar dagang Indonesia di Thailand yang siap membantu dalam bidang perdagangan dan industri kepada masyarakat Indonesia di Indonesia. Adanya aktivitas organisasi INTCC di Indonesia juga dapat menjalin hubungan yang erat dengan pemerintah Indonesia secara langsung khusunya melalui kementrian perdagangan.

Berdasarkan penjabaran di atas, pada tabel berikut ini disampaikan hasil implementasi teori dan konsep yang digunakan di dalam penelitian.

Tabel 1. Keseluruhan Pembahasan Hasil Penelitian

\begin{tabular}{llll}
\hline No & Konsep & Interpretasi & Keterangan \\
\hline 1 & Penerapan & -INTCC sama seperti organisasi lainnya memiliki struktur Organisasi INTCC sesuai \\
& Tujuan, Visi dan & organisasi, visi dan misi, anggota organisasi serta aktivitas teori FFST premis pertama. \\
& Misi Indonesia- & komunikasi organisasi INTCC. INTCC hampir memenuhi & \\
\hline
\end{tabular}


Thai Chamber of seluruh premis dari Fully Functional Society Theory . Premis Commerce (INTCC) pertama, Ketua INTCC pada saat ini (2017-2018) Chandra Jokowidjaja cukup berpengalaman di dalam bidang bisnis agrikultur, ekspor dan impor dan memiliki network yang besar di Thailand. Beliau juga mempunyai rencana untuk meningkatkan jumlah diaspora Indonesia sesuai dengan tujuan organisasi melalui berbagai aktivitas yang akan ditingkatkan.

- Stakeholders INTCC yaitu pengusaha Indonesia di Thailand, pengusaha Thailand di Thailand, pemerintah Indonesia, masyarakat Indonesia di Thailand, masyarakat Thailand di Thailand dan masyarakat Indonesia di Indonesia, pemerintah Thailand, Pemerintah Indonesia, komunitas Indonesia di Thailand dan komunitas Thailand di Thailand.

- Aktivitas organisasi INTCC yang diselenggarakan selama ini dalam bentuk business matching, pameran bisnis, seminar \& talkshow, Social Work, Networking night, dan turnamen olahraga.

\begin{tabular}{ll}
\hline 2 & Hubungan \\
& INTCC dengan \\
& anggota Member \\
& INTCC \\
& (Pengusaha \\
& Indonesia di \\
& Thailand dan \\
& Pengusaha \\
& Thailand di \\
& Thailand)
\end{tabular}

- Pengusaha Indonesia

-Teori FFST premis kedua dan premis ketiga dimana organisasi melayani masyarakat dengan mempekerjakan pelobi dan pakar perdagangan untuk kedua negara yang dapat membantu penyelesaian masalah. Melalui pertemuan diplomasi dagang, Business Forum, Business Matching dan acara pertemuan bisnis lainnya

- Teori FFST dalam premis keempat (tidak sesuai). Adanya

di kepentingan pribadi pengusaha Indonesia di Thailand menyebabkan sikap acuh tak acuh dan mengutamakan bisnisnya daripada menjalankan fungsi organisasi.

- Teori FFST Premis kelima (tidak sesuai). Agenda pertemuan rutin yang dilakukan INTCC juga masih tergolong sedikit dengan melakukan pertemuan rutin sebanyak 1-2 kali dalam 1 bulan. Hal sehingga sulit untuk organisasi INTCC menemukan solusi dari permasalahan internal maupun eksternal organisasi.

- Teori Fusion Theory pada proses personalisasi yaitu Social Status INTCC. Sebagai Pengusaha mempunyai kesibukan dengan kepentingan bisnisnya masing-masing sehingga roda organisasi INTCC berjalan lambat.

- Pengusaha Thailand

- Teori FFST premis ketujuh: Pengusaha Thailand turut mendukung pertemuan diplomasi dagang, Business Forum, Business Matching dan acara pertemuan bisnis lainnya.

- Teori FFST premis kedelapan: INTCC lebih banyak memfasilitasi perusahaan Thailand yang ingin memperluas bisnis atau berinvestasi bersama di Indonesia atau mencari kemitraan atau berinvestasi di Indonesia.

- Premis Fusion Theory pada proses sosialisasi yaitu Organizational Structure INTCC ditemukan tidak sesuai karena tidak ada partisipasi dari pengusaha Thailand di Jajaran BOD INTCC.

$3 \quad \begin{aligned} & \text { Hubungan } \\ & \text { INTCC dengan }\end{aligned}$

Masyarakat

Indonesia

Masyarakat

Thailand

Thailand
Pengusaha Indonesia

-Sesuai dengan teori FFST premis kedua dan premis ketiga

-Tidak sesuai dengan teori

FFST dalam premis

keempat, Premis kelima,

Fusion Theory (Social

Status INTCC)

Pengusaha Thailand

-Sesuai dengan Teori FFST premis ketujuh, premis kedelapan

-Tidak sesuai dengan

Teori Fusion Theory

(Organizational

Structure)

\section{- Masyarakat Indonesia}

- Teori FFST premis kedua: seminar, Workshop, pameran investasi dan pertandingan olahraga, tidak hanya melibatkan dan pengusaha tetapi juga masyarakat Indonesia di Thailand.

- Teori FFST premis kedelapan: mewakili masyarakat

di Indonesia di Thailand melalui event Thailand seperti Thai National Day, membantu masyarakat Indonesia bersama Sesuai dengan Teori

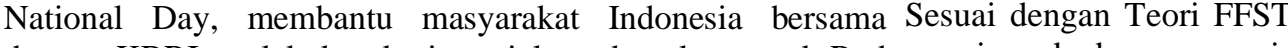
dengan KBRI, melakukan kerja sosial sumbangkan untuk Red premis kedua, premis Cross, membantu kerjasama Suphaburi FC dengan Bali FC kedelapan, konsep dalam pertukaran pemain dan menggalang diaspora Indonesia diplomasi Publik dimensi di Thailand.

- Masyarakat Thailand

Masyarakat Indonesia
Sesuai dengan Teori
FFST premis kedua,
Premis kedelapan
Masyarakat Thailand
Sesuai dengan Teori FFST
premis kedua, premis
kedelapan, konsep
diplomasi Publik dimensi
Soft Power (People to
people)


- Teori FFST premis kedua: melakukan program coorporate social responsibility (CSR) yaitu pemberian donasi pada Red Cross Thailand bantuan yatim piatu dan membantu yayasan amal di Wat Pho.

- Teori FFST premis kedelapan: INTCC membantu mencari informasi mengenai cara berinvestasi di Indonesia, mencari distributor di Indonesia, informasi seminar dan Trade Expo di Indonesia

- Konsep diplomasi Publik dimensi Soft Power (People to people): acara social event yang dilakukan bersama KBRI Bangkok untuk masyarakat Thailand

\begin{tabular}{|c|c|c|c|}
\hline 4 & $\begin{array}{l}\text { Hubungan } \\
\text { INTCC dengan } \\
\text { Masyarakat } \\
\text { Indonesia di } \\
\text { Indonesia }\end{array}$ & $\begin{array}{l}\text { - Teori FFST premis kedua (tidak sesuai) : Tidak ada aktivitas } \\
\text { organisasi INTCC yang dilakukan di Indonesia secara khusus } \\
\text { untuk masyarakat Indonesia di Indonesia } \\
\text { - Teori FFST premis ketiga (tidak sesuai) : Tidak ada aktivitas } \\
\text { organisasi INTCC yang dilakukan di Indonesia secara khusus } \\
\text { untuk masyarakat Indonesia di Indonesia } \\
\text { - Konsep diplomasi Publik dimensi Soft Power } \\
\text { (Cultural Interactions): penggunaan media internet yaitu } \\
\text { media sosial Facebook, line Group dan email untuk } \\
\text { berkomunikasi langsung dengan masyarakat Indonesia }\end{array}$ & $\begin{array}{l}\text {-Sesuai dengan konsep } \\
\text { diplomasi Publik dimensi } \\
\text { Soft Power (Cultural } \\
\text { Interactions) } \\
\text {-Tidak sesuai dengan teori } \\
\text { FFST premis kedua, premis } \\
\text { ketiga }\end{array}$ \\
\hline 5 & \begin{tabular}{lr}
\multicolumn{2}{l}{ Hubungan } \\
INTCC & dengan \\
Kedutaan & Besar \\
Republik & \\
Indonesia & di \\
Bangkok &
\end{tabular} & $\begin{array}{l}\text { - Teori FFST premis ketujuh: Peran KBRI Bangkok sebagai } \\
\text { pelindung INTCC, KBRI Bangkok turut aktif dalam } \\
\text { mendukung aktivitas organisasi INTCC dengan } \\
\text { mempromosikan dan mengundang delegasi perwakilan negara } \\
\text { lainnya yang ada di Thailand. } \\
\text { - Konsep diplomasi Publik dimensi Soft Power (Political \& } \\
\text { Economic Interactions): membantu berdirinya INTCC, } \\
\text { Memajukan perekonomian Indonesia }\end{array}$ & $\begin{array}{l}\text { - Sesuai dengan Teori } \\
\text { FFST premis ketujuh, } \\
\text { Konsep diplomasi Publik } \\
\text { dimensi Soft Power } \\
\text { (Political \& Economic } \\
\text { Interactions) }\end{array}$ \\
\hline 6 & $\begin{array}{l}\text { Hubungan } \\
\text { INTCC dengan } \\
\text { Pemerintah } \\
\text { Indonesia dan } \\
\text { Pemerintah } \\
\text { Thailand }\end{array}$ & $\begin{array}{l}\text { • Pemerintah Indonesia } \\
\text { - Perwakilan pemerintah Indonesia di Bangkok yaitu KBRI } \\
\text { Bangkok } \\
\text { - Peran pemerintah Indonesia secara langsung belum ada } \\
\text { seiring tidak adanya aktivitas organisasi INTCC di Indonesia } \\
\text { secara khusus } \\
\text { • Pemerintah Thailand } \\
\text { - Teori FFST premis ketujuh: berkontribusi dalam berdirinya } \\
\text { INTCC terdaftar dibawah Joint Foreign of Chamber of } \\
\text { Commerce (JFCCT) dan kementrian perdagangan Thailand. }\end{array}$ & $\begin{array}{l}\text { Pemerintah Indonesia } \\
\text {-Lihat hubungan INTCC } \\
\text { dengan KBRI Bangkok } \\
\text { Pemerintah Thailand } \\
\text { - Sesuai dengan Teori } \\
\text { FFST premis ketujuh } \\
\text { - Tidak sesuai dengan } \\
\text { f konsep diplomasi Publik } \\
\text { dimensi Soft Power } \\
\text { organisasi }\end{array}$ \\
\hline
\end{tabular}

- Konsep diplomasi Publik dimensi Soft Power organisasi (Political \& Economic INTCC (Political \& Economic Interactions): (tidak sesuai) Interactions)

Pemerintah Thailand secara hubungan politik membantu INTCC secara konkrit dalam perizinan mendirikan organisasi INTCC terdaftar dalam kementrian perdagangan Thailand tetapi tidak dalam hubungan ekonomi

\begin{tabular}{|c|c|c|c|}
\hline 7 & $\begin{array}{l}\text { Hubungan } \\
\text { INTCC dengan } \\
\text { Komunitas } \\
\text { Indonesia } \\
\text { Thailand di } \\
\text { Komunitas } \\
\text { Thailand } \\
\text { Thailand }\end{array}$ & $\begin{array}{l}\text { - Komunitas Indonesia } \\
\text { - Teori FFST premis kedua: acara PERMITHA yang dibuat } \\
\text { oleh para mahasiswa Indonesia di Thailand dan acara } \\
\text { social event bersama Dharma Wanita } \\
\text { - Konsep diplomasi Publik dimensi Soft Power } \\
\text { (Cultural Interactions) : mengkomunikasikan diaspora } \\
\text { Indonesia kepada masyarakat Thailand di Thailand. } \\
\text { - Komunitas Thailand } \\
\text { - Teori FFST premis kedua : Thai Chamber of commerce, } \\
\text { Asosiasi Rice Export, Thai Otomotive, Kassat University. } \\
\text { - Konsep diplomasi Publik dimensi Soft Power } \\
\text { (Cultural Interactions): Social Event, donasi di Wat pho }\end{array}$ & 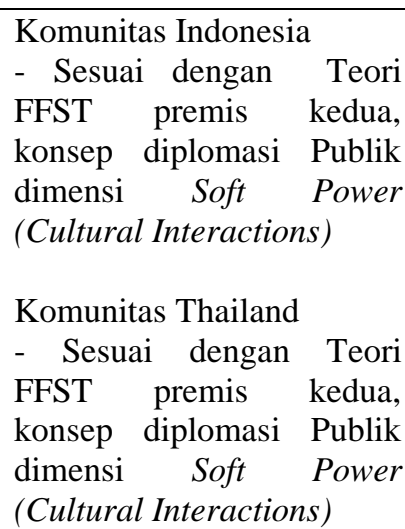 \\
\hline
\end{tabular}




\section{SIMPULAN}

Organisasi INTCC merupakan organisasi kamar dagang IndonesiaThailand yang bekerja sama dengan KBRI Bangkok dan bertujuan untuk membantu pengusaha Indonesia di Thailand. Aktivitas komunikasi organisasi INTCC terhadap pengusaha Indonesia di Thailand dikaji melalui teori utama fully functioning society theory (FFST) dan konsep diplomasi publik. Hasil penelitian ini mengidentifikasi stakeholders utama organisasi INTCC adalah: (1) Pengusaha Indonesia di Thailand, (2) Pengusaha Thailand di Thailand, (3) Pemerintah Indonesia, (4) Masyarakat Indonesia di Thailand, (5) Masyarakat Thailand di Thailand, (6) Masyarakat Indonesia di Indonesia, (7) Pemerintah Thailand, (8) Pemerintah Indonesia, (9) Komunitas Indonesia di Thailand dan (10) Komunitas Thailand di Thailand. Berdasarkan analisis terhadap data yang didapat, maka dapat disimpulkan bahwa aktivitas organisasi yang dilakukan oleh INTCC yang juga mendapat dukungan dari KBRI Bangkok pada kenyataannya masih kurang didukung oleh sebagian stakeholders utama organisasi.

Faktor penyebab terjadinya disfungsi organisasi semacam INTCC ini adalah kegagalan dalam mengidentifikasi stakeholers organisasi yang beragam serta menjaga keseimbangan dalam mengakomodasi semua kepentingan stakeholders yang telah berhasil diidentifikasi tadi, social capital yang gagal terbentuk melalui interaksi di berbagai media baik yang bersifat tatap muka maupun digital, serta kelemahan dalam penggunaan bahasa lokal (Thailand). Namun demikian, satu hasil penelitian yang menonjol adalah terjadi tidaknya proses engagement sesungguhnya tidak ditentukan oleh lokasi dimana organisasi itu berada. Karena dukungan terbatas diberikan baik oleh pengusaha Indonesia yang ada di Thailand maupun masyarakat Indonesia yang berada di Indonesia. Hal ini menunjukkan bahwa kualitas relasi lebih ditentukan oleh proses penciptaan makna dan pilihan media yang digunakan dalam interaksi dan tidak lagi terikat dengan waktu serta lokasi dimana oganisasi dan stakeholders itu berada.

\section{UCAPAN TERIMA KASIH}

Selama proses penulisan penelitian ini penulis banyak mendapat bantuan, dukungan, bimbingan, saran, petunjuk serta dorongan, baik secara moril maupun spiritual dari berbagai pihak. Oleh karena itu pada kesempatan ini penulis ingin menyampaikan ucapan terima kasih kepada organisasi Indonesia-Thai Chamber of Commerce di Thailand yang telah mengijinkan sebagai objek penelitian, wawancara informan dan informasi aktivitas organisasi. Penulis berterima kasih kepada Kedutaan Besar Republik Indonesia di Bangkok yang memberikan kesempatan untuk melakukan wawancara informan dan informasi data terkini mengenai perdagangan bilateral. Pihak London School of Public Relations Jakarta yang mengizinkan topik penelitian di dalam sebuah skripsi kelulusan program sarjana. Semua pihak yang tidak dapat disebutkan satu persatu yang telah memberikan dukungan dalam bentuk apapun untuk penelitian ini. 
DAFTAR PUSTAKA

Babic, M.,Fichtner, J.,Heemskerk, E.M.

(2017). States versus corporations: rethinking the power of business in international politics. The international spectator, 52(4), 20-43.

Breslin, S.,Nesadurai, H.E.S. (2017). Who governs and how? Non state actors and transnational governance in southeast asia. Journal of Contemporary Asia, 1-18.

Ferguson, M.A. (2018). Building theory in public relations: internalizational relationship as public relations paradigm. Journal of Public Relations Research, 1-16.

Hasan, E. (2010). Komunikasi Pemerintahan. Retrieved from https://media.neliti.com/media/publica tions/

Heath, R. (2011). External organization rhetoric: Bridging Management and Sociopolitical Discourse. Management Communication Quaterly, 25(3), 415435.

Johnston, K.A. (2014). Publis relations and engagement: theoritical imperatives of a multidimensional concept. Journal of Public Relations Research, 26, 381383.

Kemlu. (2017, April 28). Kementrian Luar Negeri. Retrieved from http://www.kemlu.go.id/id/berita/berit a-perwakilan/Pages/Investor--

Kim, J., \& Ni, S. (2011). The Nexus between Hallyu and soft power: Cultural public diplomacy in the era of sociological globalism. Hallyu: Influence of Korean popular culture in Asia and beyond, 132-154.

LokaData. (2018). Retrieved from Beritatagar.id: https://lokadata.beritagar.id/chart/prev iew/neraca-perdagangan-indonesiadengan-thailand-2013-20181552450471\#
Menashy, F. (2015). Understanding the roles of non-state actors in global governance:evidence from the global partnership for education. Journal of Education Policy, 31(1), 98-118.

Nye, J. S. (2008). Public diplomacy and soft power. Annals of the American Academy of Political and Social Science, 94-109.

Putri, L. D. (2014). Krisis, Ancaman atau Peluang ?! Lontar Jurnal Ilmu Komunikasi, 25-38.

Saputra, D. H. (2017, Maret 31). Retrieved from Kaltim Post: http://kaltim.prokal.co/read/news/2960 03-di-mana-peran-kadin

Setyowati, E. (2016). Diplomasi Ekonomi Kadin Jawa Tengah Dalam Meningkatkan Perdagangan Luar Negeri 2011-2012. Prosiding Seminar Nasional INDOCOMPAC, universitas Bakrie.

Skalanews. (2015, April 7). Diplomasi Ekonomi Indonesia Dorong Thailand. Retrieved from http://skalanews.com/berita/ekonomibi snis/sektor-riil/

Strange, S. (2015). States and Markets. University of Warwick.

Taylor, M. (2011). Building Social Capital Through Rhetoric and Public Relations. Journal of Communication, 436-454.

Widowati, D. (2013). Membangun Budaya Organisasi Melalui Komunikasi. Lontar Jurnal Ilmu Komunikasi, 2128.

Worldometers. (2019, Juli 3). Thailand Population (LIVE). Retrieved from Worldometers.info: https://www.worldometers.info/worldpopulation/thailand-population/

Yin, R.K. (2003). Case study research: design and methods. California : SAGE Publications.

Yovanda, Y. R. (2017, Januari 16). Perekonomian Masih Lemah Ekspor RI 
turun. Retrieved from

https://ekbis.sindonews.com/read/1171

276/33/
Zhang, W.,Alitbol, A. (2014). The role of public relations in social capital and civic engagement.Communication faculty 